\title{
Effect of split application of nitrogen on performance of wheat (Triticum aestivum L.)
}

\author{
R.K. SINGH*, PANKAJ KUMAR, BIRENDRA PRASAD', A.K. DAS AND S.B. SINGH \\ Krishi Vigyan Kendra, KATIHAR (BIHAR) INDIA \\ (Email : rksbau555@gmail.com.; mantoo555@rediffmail.com)
}

\begin{abstract}
A field experiment was conducted at farmer field of Katihar district during two consecutive years of 2012-13 and 201314 to study the yield of wheat as influenced by split application of nitrogen. The soil is non-calcareous light gray in colour flood plain belongs to the alluvial gangetic plain (Agro climatic zone II). The study was done in Randomized Block Design with four treatments and ten replications with HD 2733 wheat variety to evaluate the observation regarding growth attributes and yield components of individual plant parameters were recorded from randomly selected plants in each plot. The evaluated traits were plant population $\left(\mathrm{m}^{-2}\right)$, plant height $(\mathrm{cm})$, bearing tillers plant ${ }^{-1}$ (no.), non-bearing tillers plant ${ }^{-1}$ (no.), spikelets spike ${ }^{-1}$ (no.), fertile spikelets spike (no.) non-fertile spikelets spike $^{-1}$ (no.), 1000-seed weight (g), seed yield ( $\left.\mathrm{t} \mathrm{ha}^{-1}\right)$ and straw yield $\left(\mathrm{t} \mathrm{ha}^{-1}\right)$. Results indicated that the use of three split $\mathrm{N}$ applications increased all growth and yield attributes. The best $\mathrm{N}$ split strategy corresponded to three $\mathrm{N}$ splits: at planting, crown root initiation (CRI), and panicle initiation (PI) stages.
\end{abstract}

Key Words : Wheat, Split doses, Nitrogen, Growth, Yield components

View Point Article : Singh, R.K., Kumar, Pankaj, Prasad, Birendra, Das, A.K. and Singh, S.B. (2016). Effect of split application of nitrogen on performance of wheat (Triticum aestivum L.). Internat. J. agric. Sci., 12 (1) : 32-37.

Article History : Received : 30.06.2015; Revised : 14.11.2015; Accepted : 27.11.2015

\footnotetext{
* Author for correspondence :

${ }^{1}$ Regional Research Station, Agwanpur, SAHARSA (BIHAR) INDIA (Email: birendragbau@gmail.com)
} 